\title{
Virtual Water in Food Production
}

\section{Introduction}

The water consumed in the production process of an agricultural or industrial product has been called the 'virtual water' contained in the product (Allan 1998). If one country exports a water intensive product to another country, it exports water in virtual form. In this way some countries support other countries in their water needs. For water-scarce countries it could be attractive to achieve water security by importing water-intensive products instead of producing all water demanding products domestically (WWC 1998). Reversibly, water-rich countries could profit from their abundance of water resources by producing water-intensive products for export. Trade of real water between water-rich and water-poor regions is generally impossible due to the large distances and associated costs, but trade in water-intensive products (virtual water trade) is realistic (Hoekstra and Hung 2002). Virtual water trade between nations and even continents could thus ideally be used as an instrument to improve global water use efficiency, to achieve water security in water-poor regions of the world and to alleviate the constraints on environment by using best suited production sites (Turton 2000).

\section{Primary product}

Cereals, vegetables and fruits fall into this category for which the relationship between water consumption and production is quite clear. Production $(\mathrm{kg})$ and water evapotranb spired $\left(\mathrm{m}^{3}\right)$ are estimated at field level and are the basis of the virtual water value estimation $\left(\mathrm{m}^{3} /\right.$ $\mathrm{kg}$ ), possibly adjusted with efficiency factors. These products are assessed as primary products even though sometimes transformed afterwards (e.g. fruit juice).

\section{Processed products}

These are the food items that are produced by processing primary products. Vegetal processed products include sugar (sugarcane, sugar beet), oil from various primary product, and alcoholic beverages.

\section{Transformed products}

Animal products must be considered as transformed products as their production using primary vegetal products (cereals, grass, other by-products). Two continents, America and Oceania, are net exporters of virtual water. They represent $51 \%$ of the exported virtual water. In particular, the exports of Oceania are much more important than theirown consumption. Two continents, Asia and Africa, are net importers of virtual water. They represent $46 \%$ of the imported virtual water. European Union occupies a specific place since it imports and exports high quantities of virtual water with a net balance almost equal to zero. It is right time for Nepal to consider virtual water to take advantages of its vast unused water sources that is flowering act of the country.

\section{Appendix}

Table A1. Specific Water Demands or primary vegetal products (Values estimated for 1990)

\begin{tabular}{|l|l|l|}
\hline Products & $\begin{array}{l}\text { Specific } \\
\text { Water } \\
\text { Demand } \\
\mathbf{~ m} \mathbf{3}^{\mathbf{3}} \mathbf{T} \mathbf{)}\end{array}$ & Country, Reference \\
\hline Wheat, millet, rye & 1159 & California, Barthelemy et al \\
\hline Barley & 1910 & California, Barthelemy et al \\
\hline Sorghum & 542 & Egypt, Barthelemy et al \\
\hline Rice & 1408 & California, Barthelemy et al \\
\hline Maize & 710 & California, Barthelemy et al \\
\hline Cereals, others & 1159 & California, Barthelemy et al \\
\hline Sugar beet & 193 & California, Barthelemy et al \\
\hline Sugar Cane & 318 & California, Barthelemy et al \\
\hline Pulses & 1754 & $\begin{array}{l}\text { Egypt, Barthelemy et al, TS and } \\
\text { FAO databases }\end{array}$ \\
\hline Sunflower & 3283 & $\begin{array}{l}\text { Egypt, Barthelemy et al, TS } \\
\text { databases }\end{array}$ \\
\hline Tomatoes & 130 & California, Barthelemy et al \\
\hline $\begin{array}{l}\text { Oranges and other } \\
\text { citrus }\end{array}$ & 378 & California, Barthelemy et al \\
\hline
\end{tabular}

Table A2. Specific Water Demands or transformed or processed products (Values estimated for 1990)

\begin{tabular}{|c|c|c|}
\hline Products & $\begin{array}{c}\text { Specific } \\
\text { Water } \\
\text { Demand } \\
\left(\mathrm{m}^{3} / \mathrm{T}\right)\end{array}$ & Country, Reference \\
\hline Sunflower seed oil & 7550 & California, Barthelemy et al \\
\hline Rape and Mustard oil & 3500 & Germany, BRL data base \\
\hline Soybean oil & 5405 & $\begin{array}{l}\text { Egypt, Barthelemy et al, TS and FAO } \\
\text { databases }\end{array}$ \\
\hline $\begin{array}{l}\text { Bovine, mutton, goat } \\
\text { meat }\end{array}$ & 13500 & California, Barthelemy et al \\
\hline Pig meat & $4600^{1}$ & California, Barthelemy et al \\
\hline Poultry meat & 4100 & California, Barthelemy et al \\
\hline Other meat & 13500 & California, Barthelemy et al \\
\hline Eggs & 2700 & California, Barthelemy et al \\
\hline Milk & 790 & California, Barthelemy et al \\
\hline Butter + Fat & 18000 & California, Barthelemy et al \\
\hline
\end{tabular}

${ }^{1}$ value to be debated in countries where pig is fed mainly with waste products

This write up is borrowed from Virtual Water in Food Production and Global Trade Review of Methodological Issues and Preliminary Results, written by Daniel ZIMMER and Daniel RENAULT, World Water Council, FAO-AGLW. This is duly acknowledged. 